\title{
Life Cycle of Chrysaora fuscescens (Cnidaria: Scyphozoa) and a Key to Sympatric Ephyrae ${ }^{1}$
}

\author{
Chad L. Widmer ${ }^{2}$
}

\begin{abstract}
The life cycle of the Northeast Pacific sea nettle, Chrysaora fuscescens Brandt, 1835 , is described from gametes to the juvenile medusa stage. In vitro techniques were used to fertilize eggs from field-collected medusae. Ciliated planula larvae swam, settled, and metamorphosed into scyphistomae. Scyphistomae reproduced asexually through podocysts and produced ephyrae by undergoing strobilation. The benthic life history stages of $C$. fuscescens are compared with benthic life stages of two sympatric species, and a key to sympatric scyphomedusa ephyrae is included. All observations were based on specimens maintained at the Monterey Bay Aquarium jelly laboratory, Monterey, California.
\end{abstract}

The Northeast Pacific sea nettle, Chrysaora fuscescens Brandt, 1835, ranges from Mexico to British Columbia and generally appears along the California and Oregon coasts in late summer through fall (Wrobel and Mills 1998). Relatively little is known about the biology or ecology of C. fuscescens, but when present in large numbers it probably plays an important role in its ecosystem because of its high biomass (Shenker 1984, 1985). Chrysaora fuscescens eats zooplankton and is in turn preyed upon by leatherback sea turtles, Dermochelys coriacea (Vandelli, 1761), and ocean sunfish, Mola mola (Linnaeus, 1758) (Arai 2005). Medusae of $C$. fuscescens also serve as temporary homes for several hitchhiking symbionts, including juvenile slender crabs, Cancer gracilis Dana, 1852 (Wrobel and Mills 1998), and juveniles of fishes Icichthys lockingtoni Jordan \& Gilbert, 1880, and Peprilus simillimus (Ayres, 1860) (pers. obs.).

Cultures of $C$. fuscescens have been main-

\footnotetext{
${ }^{1}$ Manuscript accepted 14 April 2007.

${ }^{2}$ Husbandry Division, Monterey Bay Aquarium, 886 Cannery Row, Monterey, California 93940 (phone: 831647-4511; fax: 831-644-7597; e-mail: cwidmer@mbayaq .org).
}

Pacific Science (2008), vol. 62, no. 1:71-82

(C) 2008 by University of Hawai'i Press

All rights reserved tained at the Monterey Bay Aquarium, Monterey, California, for over a decade, with cultures started by F. Sommer, D. Wrobel, B. B. Upton, and C.L.W. However the life cycle remained undescribed. Chrysaora fuscescens belongs to the family Pelagiidae (Gershwin and Collins 2002), medusae of which are characterized as having a central stomach giving rise to completely separated and unbranched radiating pouches and without a ring-canal. The tentacles of the medusae arise from the umbrella margin between the clefts of the lappets; the oral arms are long, pointed, and highly folded (Kramp 1961). The life cycle of C. fuscescens is described here based on laboratory observations at the Monterey Bay Aquarium and is compared with life cycles of sympatric coastal scyphomedusae.

\section{MATERIALS AND METHODS}

Twelve mature Chrysaora fuscescens medusae ranging in size from 19 to $35 \mathrm{~cm}$ in bell diameter (Figure 1) were collected with handheld dip nets from the surface waters of Monterey Bay, California, in January 2006, aboard the RV Plankton Boat, a 19-foot-long $(5.8 \mathrm{~m})$ Boston Whaler. Medusae were transported to the jelly laboratory at the Monterey Bay Aquarium where in vitro techniques were completed less than $1 \mathrm{hr}$ after arrival. Four of the medusae collected were mature females and the rest were mature males. 


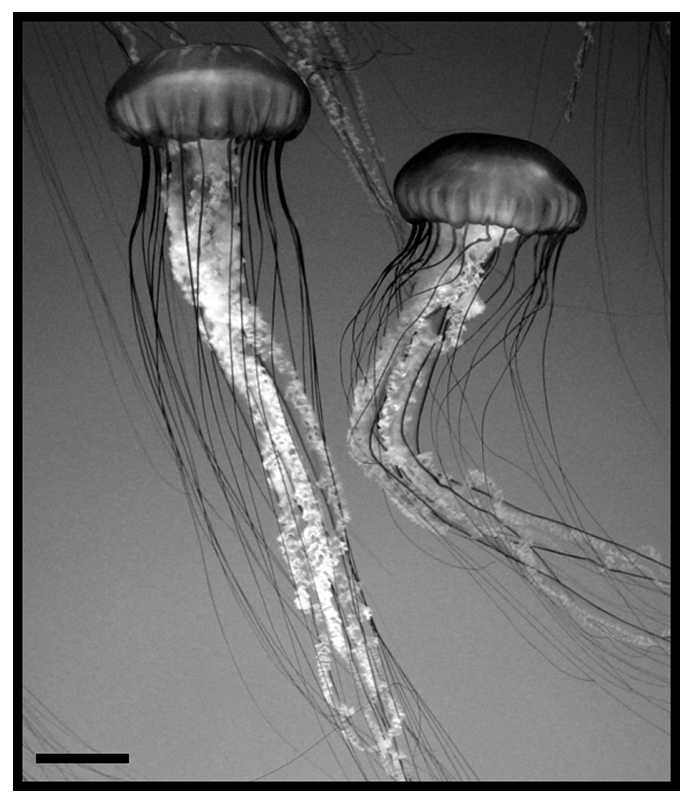

Figure 1. Mature medusae of Chrysaora fuscescens. Scale bar $=10 \mathrm{~cm}$.

\section{In Vitro Techniques}

Fine-tipped forceps were used to remove small samples of gonad from the four mature females and four randomly selected mature male medusae. The gonad samples were mixed together inside a $20 \mathrm{~cm}$-diameter glass culture dish filled with 1 liter of $0.05 \mu \mathrm{m}$ filtered natural seawater. Because C. fuscescens is a broadcast spawner and its gametes are fertilized externally it was appropriate to mix gametes from several individuals for the in vitro fertilization. The dishes were partially submerged on seawater tables to maintain the temperature at $14^{\circ} \mathrm{C}$. When planulae developed after about 2 days, gonad materials were removed from the dishes to prevent fouling, and the planulae were separated into five additional $20 \mathrm{~cm}$-diameter culture dishes, with roughly 500 planulae per liter.

\section{Scyphistoma (Polyp) Rearing}

The $20 \mathrm{~cm}$-diameter dishes were maintained on seawater tables in temperature-controlled baths at $14^{\circ} \mathrm{C}$ until the planulae settled and metamorphosed into scyphistomae. Planulae settled on the bottoms and sides of the dishes or on the underside of the water surface tension. Planulae that settled on the surface tension were harvested by floating smaller 4inch-diameter $(10 \mathrm{~cm})$ glass culture dishes on the surface of the water. This method worked well for encouraging developing polyps to attach on the bottom and sides of the floating glass dishes. When polyps reached the eighttentacled stage of development they were submerged in a small rectangular tank with gently flowing (ca. 0.5 liters $/ \mathrm{min}$ ) $5 \mu \mathrm{m}-$ filtered seawater in a flow-through configuration (Raskoff et al. 2003) at $14^{\circ} \mathrm{C}$.

\section{Feeding}

Developing scyphistomae were fed rotifers, Brachionus plicatilis (Müller, 1786), daily until the polyps reached the eight-tentacled stage of development. At the eight-tentacled stage they were large enough to eat Artemia franciscana Kellogg, 1906, nauplii. Each day developing medusae were fed Artemia nauplii and chopped, cultured moon jellies, Aurelia labiata Chamisso \& Eysenhardt, 1821.

\section{Documentation}

The terms used to describe the morphology of the life history stages of $C$. fuscescens were defined by Arai (1997). All of the life history stages were measured with a measuring ocular calibrated such that there were 10 divisions per millimeter. Specimens were placed on the microscope stage and allowed $1 \mathrm{~min}$ to relax before each measurement was taken. Specimens were photographed using a digital camera (Nikon Coolpix 950) mounted on a dissecting stereomicroscope (Leica Wild M8) and a compound light microscope (Olympus BX40).

\section{Statistics}

The statistical program SPSS 13.0 was used to analyze collected data and report the descriptive statistics. One-way analysis of 
variance (ANOVA) tests were conducted to determine the significance of size of compared morphological structures for ephyra of given species. The assumption of normality was checked and verified using a normal probability plot. The assumption of homoscedasticity was checked using a Levene test.

\section{RESULTS}

All measurements are reported as means. The development times for a single randomly selected culture dish consisting of 20 initially settled planulae are presented in Table 1 . Morphological variation for specific structures of early life history of $C$. fuscescens stages is given in Table 2 based on randomly selected specimens produced in vitro.
TABLE 1

Development Time for One Culture Dish of Chrysaora fuscescens Starting with 20 Settled Planulae

\begin{tabular}{ll}
\hline \hline Time & \multicolumn{1}{c}{ Stage of Development } \\
\hline $0 \mathrm{hr}$ & Unfertilized gametes \\
$2 \mathrm{hr}$ & 2 cells \\
$3 \frac{1}{2} \mathrm{hr}$ & 4 cells \\
$5 \mathrm{hr}$ & 8 cells \\
$7 \frac{1}{2} \mathrm{hr}$ & 16 cells \\
Day 2 & Swimming planulae \\
Day 3 & Planulae settlement \\
Day 7 & Two-tentacled polyp \\
Day 12 & Four-tentacled polyp \\
Day 19 & Eight-tentacled polyp \\
Day 22 & Early 16-tentacled polyp \\
Day 50-55 & Mature 16-tentacled polyp (Figure 3A,B) \\
Day 231 & Strobilae formed (Figure 4) \\
Day 286 & First ephyra released (Figure $8 A)$ \\
\hline
\end{tabular}

Note: The culture was started in January 2006 at Monterey Bay Aquarium and maintained at $14^{\circ} \mathrm{C}, 34 \mathrm{ppt}$.

TABLE 2

Morphological Character Variation of Early Life History Stages and Developing Scyphistomae of Chrysaora fuscescens

\begin{tabular}{|c|c|c|c|}
\hline \multirow[b]{2}{*}{ Character } & \multicolumn{3}{|c|}{ Measurements } \\
\hline & Mean & SD & Range \\
\hline \multicolumn{4}{|l|}{ Eggs $(\mu \mathrm{m})$} \\
\hline Length & 134.5 & 9.84 & $120-150$ \\
\hline Width & 114.5 & 4.97 & $110-120$ \\
\hline \multicolumn{4}{|l|}{ Spermatophores $(\mu \mathrm{m})$} \\
\hline Length & 174.5 & 45.73 & $110-260$ \\
\hline Width & 113 & 26.68 & $70-150$ \\
\hline \multicolumn{4}{|l|}{ Planula $(\mu \mathrm{m})$} \\
\hline Length & 181 & 28.46 & $160-260$ \\
\hline Width & 92.9 & 5.04 & $85-100$ \\
\hline \multicolumn{4}{|c|}{ Two-tentacled stage polyp (mm) } \\
\hline Tentacle length & 0.19 & 0.013 & $0.17-0.22$ \\
\hline Hypostome height & 0.097 & 0.007 & $0.08-0.11$ \\
\hline Polyp height & 0.573 & 0.053 & $0.45-0.62$ \\
\hline Polyp oral disk width & 0.221 & 0.014 & $0.2-0.25$ \\
\hline \multicolumn{4}{|c|}{ Four-tentacled stage polyp (mm) } \\
\hline Tentacle length & 1.09 & 0.073 & $1-1.2$ \\
\hline Polyp height & 0.64 & 0.034 & $0.6-0.71$ \\
\hline Polyp oral disk width & 0.29 & 0.023 & $0.25-0.34$ \\
\hline \multicolumn{4}{|c|}{ Eight-tentacled stage polyp (mm) } \\
\hline Tentacle length & 1.12 & 0.14 & $0.4-0.9$ \\
\hline Polyp height & 0.67 & 0.073 & $0.6-0.8$ \\
\hline Polyp oral disk width & 0.36 & 0.027 & $0.32-0.4$ \\
\hline \multicolumn{4}{|c|}{ 16-tentacled stage polyp (mm) } \\
\hline Tentacle length & 1.51 & 0.358 & $0.9-1.1$ \\
\hline Polyp height & 0.88 & 0.092 & $0.75-1$ \\
\hline Polyp oral disk width & 0.72 & 0.056 & $0.65-0.81$ \\
\hline
\end{tabular}

Note: Measurements for eggs and spermatophores were taken from one typical female and male medusa, respectively $n=10$. For each scyphistoma developmental stage 10 specimens each were measured from randomly selected dishes. 


\section{Gonads}

The ovaries contained eggs in various stages of development. Mature eggs were $134.5 \mu \mathrm{m}$ long and $114 \mu \mathrm{m}$ wide and were densely packed on the gonad. Sperm were produced in irregularly shaped follicles ca. $174.5 \mu \mathrm{m}$ long by $113 \mu \mathrm{m}$ wide. At $14^{\circ} \mathrm{C}$, development time from zygote to the 16-cells stage was about $7.5 \mathrm{hr}$ and from fertilization to planula took 1 to 2 days (Table 1 ).

\section{Planulae}

The planulae were about $181 \mu \mathrm{m}$ long and $92.9 \mu \mathrm{m}$ wide and orange-brown, more dominantly orange than brown. Planulae were completely covered by cilia and highly motile. Planulae swam for about 2 to 3 days before they settled on their aboral pole, which was bluntly rounded; the oral pole was flattened with a slight depression marking the position of the rudimentary mouth in forthcoming scyphistomae. About $80 \%$ of the planulae settled on the surface tension.

\section{Developing Scyphistoma}

By about day 7 scyphistomae produced two perradial filiform tentacles (Table 1), each about $0.19 \mathrm{~mm}$ long, and had small domedshaped hypostomes that were raised about $0.097 \mathrm{~mm}$ above the calyx. Polyps were $0.573 \mathrm{~mm}$ high, and the oral disk width was about $0.221 \mathrm{~mm}$.

Polyps developed into the four-tentacled stage around day 12 and developed a thin, periderm-covered stalk with a rounded basal attachment disk (Figure 2). The four tentacles were highly extensile and were 1.09 $\mathrm{mm}$ long. The total height of the polyps from attachment disk to hypostome was 0.64 mm. The calyx had an oral disk width of about $0.29 \mathrm{~mm}$, and gastric septa were not yet visible. The raised hypostome had a simple circular hole as a mouth. At the fourtentacled stage, polyps were easily capable of catching and eating rotifers, Brachionus plicatilis, but were not yet able to catch and eat Artemia fransiscana nauplii.

Polyps reached the eight-tentacled stage of

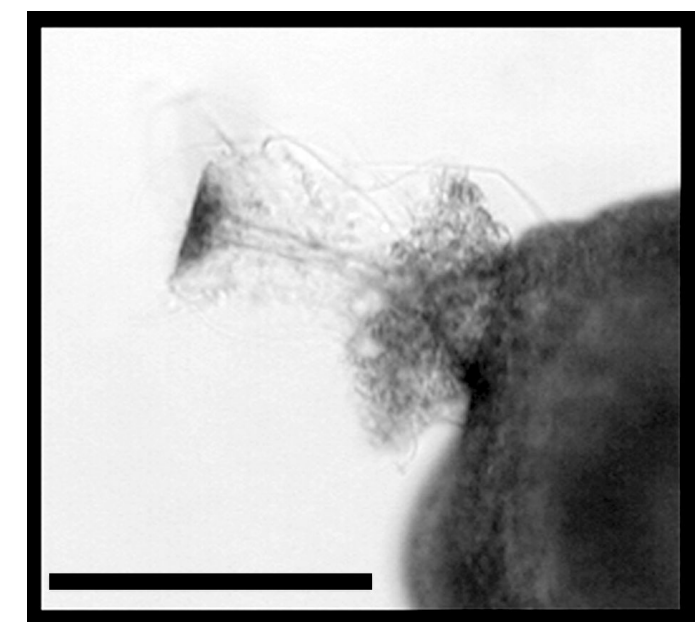

Figure 2. Basal attachment stalk of early Chrysaora fuscescens scyphistoma. Scale bar $=100 \mu \mathrm{m}$.

development by about day 19 at $14^{\circ} \mathrm{C}$ (Table 1). They were $0.67 \mathrm{~mm}$ tall, and the smaller, thinner basal attachment stalk became less distinct from the calyx, giving the polyp a conical or funnel shape overall. The tentacles were $1.12 \mathrm{~mm}$ long and the oral disks were $0.36 \mathrm{~mm}$ wide. The hypostome became clavate with distinct lips. At this stage the polyps were highly active, bending from side to side and with a mouth that opened and closed rapidly when food was present. Polyps at this stage were capable of eating Artemia nauplii; their tentacles captured the prey and then passed it to the mouth by swiping the tentacle through the lips of the manubium.

Polyps reached the early 16-tentacled stage of development by about day 22 (Table 1). They were $0.88 \mathrm{~mm}$ tall and had oral disks that were $0.72 \mathrm{~mm}$ wide. Tentacles were 1.51 $\mathrm{mm}$ long. The thin periderm-covered basal attachment stalk was still present but beginning to become overgrown by the base of the calyx as it thickened and matured.

\section{Mature Scyphistomae}

By day 50 (Table 1) mature scyphistomae of $C$. fuscescens (Figure $3 A, B$ ) were brownish orange and cylindrical to conical with the aboral end tapering into a short basal stalk. Polyps 


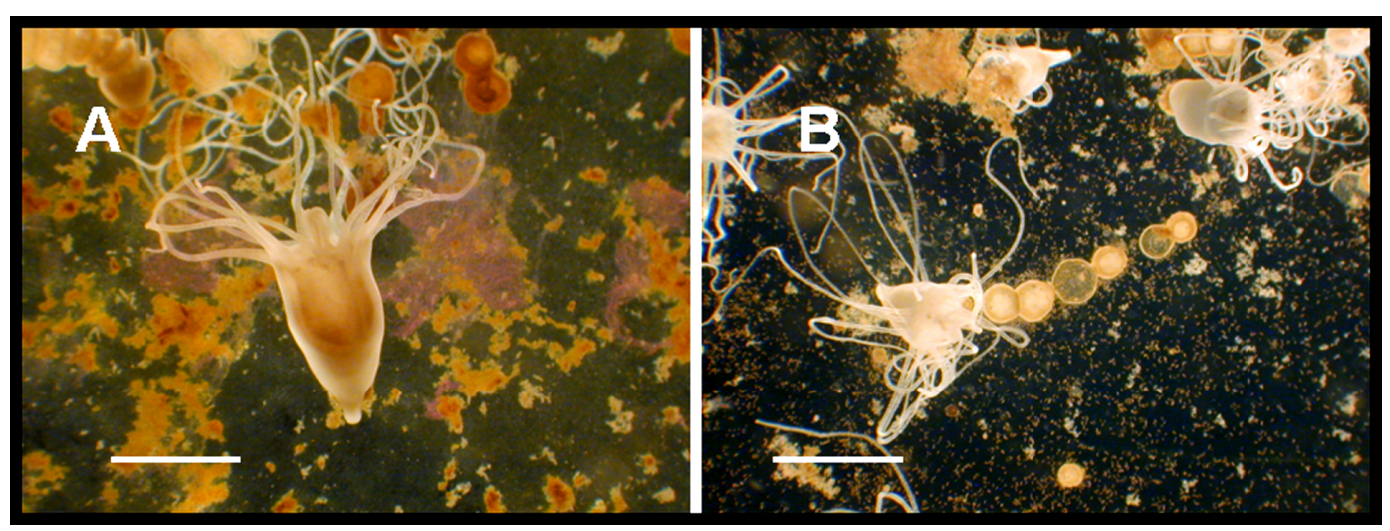

Figure 3. Mature scyphistomae of Chrysaora fuscescens. A, Mature scyphistoma. B, Scyphistoma with trail of podocysts in its wake. Scale bars $=2 \mathrm{~mm}$.

were $2.96 \mathrm{~mm}$ long and had an average oral disk diameter of $1.47 \mathrm{~mm}$. The polyps had an amphicoronate single whorl of 16 tentacles, the number being variable (15-19). The tentacles had an average length of 47 $\mathrm{mm}$ when fully extended and relaxed. The septal funnels were conspicuous and the distinct clavate mouths were raised about 0.5 $\mathrm{mm}$ from the oral disk. Polyps' mouths were very active, opening and closing frequently. Each polyp produced a single short basal stolon that actively formed golden brown, disc-shaped podocysts that had a mean diameter of $0.674 \mathrm{~mm}$. Locomotion and podocyst formation were concurrent processes (Figure $3 B$ ). It took about 4 weeks for a polyp to make a single podocyst and move past it. When polyps excysted from podocysts they followed the same pattern of tentacle development as did developing new polyps recently settled from planulae: first two tentacles, then four, eight, and 16 tentacles. On day number 231, a single polyp followed in Table 1 had asexually produced a colony consisting of 51 polyps and 53 podocysts.

\section{Strobilae}

After about 230 days, polyps initiated the process of strobilation (Table 1), which was similar to that reported for other species of scyphomedusae (Arai 1997). Upon strobilation the entire polyp lengthened, the tentacles shortened, and the polyp became thinner just below the oral disk (Figure $4 A$ ). Polyps were capable of extreme polydisc strobilation and were observed to produce up to 60 ephyrae per polyp (Figure $4 B$ ). Strobilae were light tan in color. Maturation of ephyrae was successive, with distal ephyrae pulsing and being released before proximalbasal ephyrae were fully formed. Before the last ephyrae were released, basal polyp tentacles regenerated, and after the last ephyra was released the basal polyp regenerated a mouth in about $2-3$ days. The entire process of strobilation took about 10 weeks at $14^{\circ} \mathrm{C}$.

\section{Ephyra Description}

Newly liberated ephyrae were light tan in color (Figure $8 A$ ) and had a mean diameter from lappet tip to lappet tip of $3.13 \mathrm{~mm}$. Typical, tetramerous ephyrae had eight marginal arms (rhopaliar arms) though the number infrequently was variable, ranging from 6 to 10 arms. Each arm terminated in two pointed lappets, with a single rhopalium situated in the clefts between the lappets. The arms had characteristic nematocyst batteries (Russell 1970) of the Chrysaora pattern (Gershwin and Collins 2002). At the base of each arm there were two smaller rounded nematocyst batteries, proximal to the mouth and distal to the lappets. The smaller rounded exumbrellar nematocyst batteries formed a 


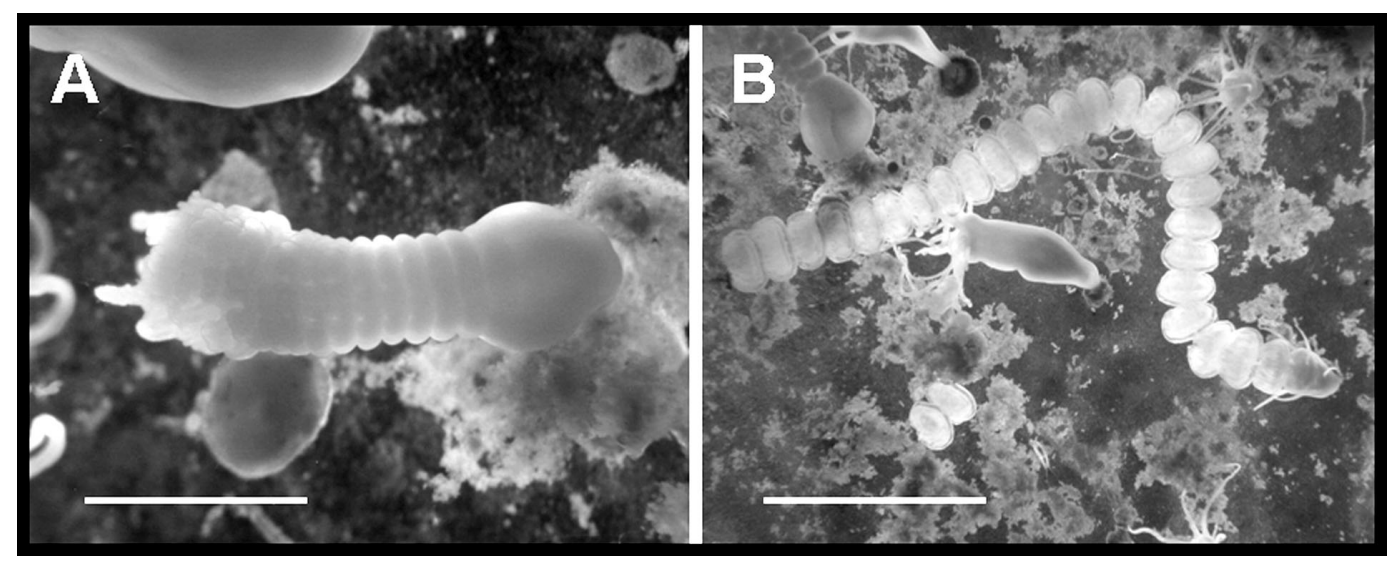

Figure 4. Strobilation of Chrysaora fuscescens. A, Neck thinning and elongating stage, transverse fission, and ephyrae formation. $B$, Late strobila stage. Scale bars $=2 \mathrm{~mm}$.

symmetric ring around the mouth of the ephyrae (Figure $8 A$ ). The mouth was simple and cruciform, and ephyrae were capable of eating Artemia nauplii as soon as they were released from their strobilae.

\section{Medusa Development}

By day 10 , ephyrae were about $5 \mathrm{~mm}$ in bell diameter, and the rudiments of eight primary tentacles had developed in subumbrellar clefts between the rhopaliar arms (Figure 5). The primary tentacles continued to grow and oral arms began to elongate until juvenile medusae reached $35-40 \mathrm{~mm}$ in bell diameter, at which time the rudiments of secondary tentacles formed in the clefts between the lappets. All tentacles and oral arms continued to elongate and no additional ones formed, culminating with a total of 24 well-formed, long, orange-red tentacles and four long, crenulated oral arms. Cultured medusae reached sexual maturity at bell diameters ranging from 15 to $20 \mathrm{~cm}$ after about 9-12 months.

\section{DISCUSSION}

The life cycle of the cultured Chrysaora fuscescens is similar to those reported for other members of the family Pelagiidae (Schaadt et al. 2001, Morandini et al. 2004). Mature medusae were broadcast spawners that re- leased gametes into the water, where the eggs were fertilized. Planulae, swam, settled, and metamorphosed into benthic scyphistomae that asexually reproduced additional scyphistomae through podocysts. Medusae were produced via strobilation. Ephyrae were representative of the family Pelagiidae in having eight rhopaliar arms with two characteristic elongated nematocyst patches on each arm (Gershwin and Collins 2002).

Living polyps of $C$. fuscescens were readily distinguishable from sympatric polyps belonging to the family Ulmaridae. The basal attachment stalk for scyphistomae of Phacellophora camtschatica (Brandt, 1835) is surrounded by a transparent funnel-shaped periderm that is plainly visible with a dissecting microscope in mature scyphistomae (Widmer 2006). Polyps of C. fuscescens also possessed a basal attachment stalk that was surrounded by a thin periderm sheath. The sheath was present from the four-tentacled stage to the early 16-tentacled stage, but the sheaths eventually may be overgrown by the base of the scyphistoma and not visible in mature polyps. Polyps of Aurelia labiata were not reported to possess visible peridermcovered attachment stalks, and asexually reproduced polyps by side budding, stolon budding (Gershwin 2001) and with yellow green podocysts. Polyps of $C$. fuscescens had an average of 16.3 tentacles each (range 15-19), 


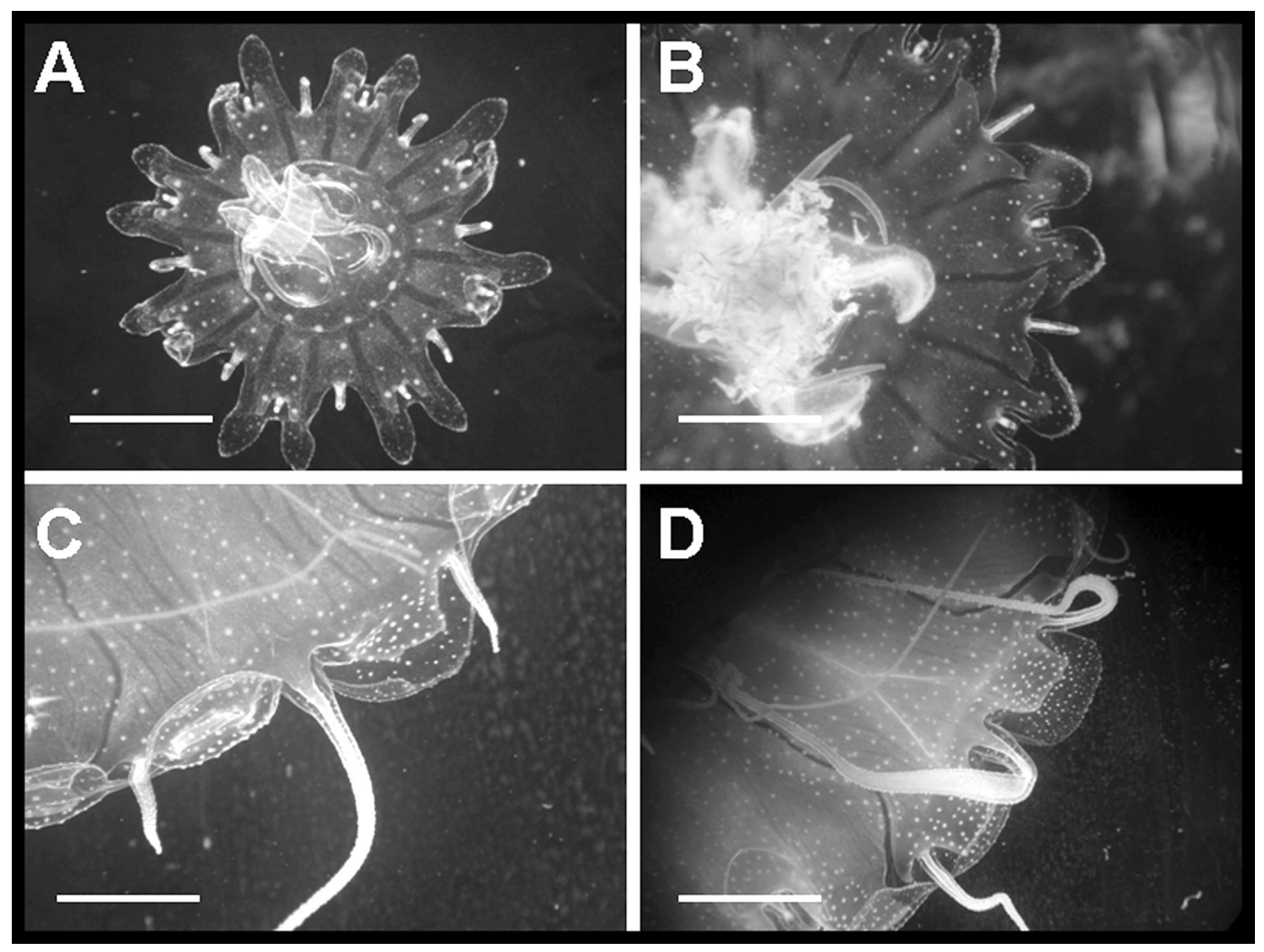

Figure 5. Juvenile medusa development of Chrysaora fuscescens. A, Late ephyra with rudiments of primary tentacles forming. $B$, Secondary tentacles forming. $C$, Secondary tentacles developing. $D$, Later secondary tentacles stage. Scale bars $=1 \mathrm{~mm}$.

whereas polyps of $A$. labiata and $P$. camtschatica had an average of 18.7 (range 16-21) and 37.5 (range 30-44) tentacles per polyp, respectively (pers. obs.). Caution should be used when making size-based comparisons among scyphistomae because size, shape, and asexual reproductive condition of scyphistomae are affected by natural environmental factors (Arai 1997), some of which include light (Loeb 1973, Chen et al. 1984), temperature (Loeb 1972, Chen and Ding 1983, Brewer and Feingold 1991), salinity (Purcell et al. 1999), nutritive condition (Chen et al. 1985), and dissolved oxygen (Condon et al. 2001).

One of the most effective current methods for distinguishing species of living polyps without using molecular tools is to induce or wait for strobilation to occur and identify resultant ephyrae. At Monterey Bay Aquarium, temperature is the primary agent used for induction of strobilation of target scyphistomae (Table 3). The temperature data presented here are anecdotal but proven at Monterey Bay Aquarium for the given species. To distinguish among ephyrae, the number of rhopaliar arms (called lobes by some authors), ephyra coloration, and shape of distal points of lappets and nematocyst patches may be used (Russell 1970). Table 4 provides data for five species of sympatric ephyrae raised under the same conditions. A key to the coastal Northeast Pacific Ocean scyphomedusa ephyrae most likely to be encountered (Larson 1990) is provided here based on specimens raised at Monterey Bay Aquarium. 
TABLE 3

Temperature Methods used at Monterey Bay Aquarium for Strobilation Induction of Northeast Pacific Ocean Scyphistomae

\begin{tabular}{|c|c|c|}
\hline Species & Maintenance Temperature & To Induce Strobilation \\
\hline Chrysaora fuscescens & $14^{\circ} \mathrm{C}$ & $\begin{array}{l}\text { Strobilates on own in episodic waves two to three } \\
\text { times per year at } 14^{\circ} \mathrm{C}\end{array}$ \\
\hline C. colorata & $20^{\circ} \mathrm{C}$ & $\begin{array}{l}\text { Drop temperature to } 14^{\circ} \mathrm{C} \text {, look for strobilation in } \\
5-6 \text { weeks }\end{array}$ \\
\hline C. achlyos & $20^{\circ} \mathrm{C}$ & $\begin{array}{l}\text { Drop temperature to } 14^{\circ} \mathrm{C} \text {, look for strobilation in } \\
5-6 \text { weeks }\end{array}$ \\
\hline C. melanaster & $20^{\circ} \mathrm{C}$ & $\begin{array}{l}\text { Drop temperature to } 14^{\circ} \mathrm{C} \text { for } 2 \text { weeks; then bring } \\
\text { temperature back up to } 20^{\circ} \mathrm{C} \text {; look for strobilation } \\
\text { in } 1-2 \text { weeks }\end{array}$ \\
\hline Cyanea sp. & $14^{\circ} \mathrm{C}$ & $\begin{array}{l}\text { Strobilates on own in episodic waves four to six } \\
\text { times per year at } 14^{\circ} \mathrm{C}\end{array}$ \\
\hline Phacellophora camtschatica & $14^{\circ} \mathrm{C}$ & $\begin{array}{l}\text { Strobilates on own in episodic waves four to six } \\
\text { times per year at } 14^{\circ} \mathrm{C}\end{array}$ \\
\hline Aurelia labiata & $14^{\circ} \mathrm{C}$ & $\begin{array}{l}\text { Rarely strobilates at } 14^{\circ} \mathrm{C} \text { and salinity of } 34 \mathrm{ppt} \text {; a } \\
\text { salinity shift to } 28 \mathrm{ppt} \text { is required }\end{array}$ \\
\hline
\end{tabular}

Note: This is anecdotal but functional information used in daily practice by C.L.W.

Ephyrae are rarely encountered in trawls and grow very quickly, limiting the usefulness of this key as a field guide. The main aim of the key is to aid in polyp identification via the strobilation method.

This dichotomous key for coastal ephyrae is based on living, cultured specimens main- tained at the Monterey Bay Aquarium by C.L.W. It is not intended to be all-inclusive, rather these are common scyphomedusae encountered on the sea surface along the northeastern Pacific coast. Also note that this key is based upon tetramerous individuals (i.e., individuals having one gut pouch per quadrant)

TABLE 4

Morphological Character Summary for Ephyrae of Northeast Pacific Ocean Scyphomedusae

\begin{tabular}{|c|c|c|c|c|c|}
\hline \multirow[b]{2}{*}{ Traits } & \multicolumn{2}{|c|}{ Family Ulmaridae } & \multicolumn{3}{|c|}{ Family Pelagiidae } \\
\hline & $\begin{array}{l}\text { Phacellophora } \\
\text { camtschatica }\end{array}$ & $\begin{array}{l}\text { Aurelia } \\
\text { labiata }\end{array}$ & $\begin{array}{l}\text { Chrysaora } \\
\text { fuscescens }\end{array}$ & $\begin{array}{l}\text { Chrysaora } \\
\text { achlyos }\end{array}$ & $\begin{array}{c}\text { Chrysaora } \\
\text { colorata }\end{array}$ \\
\hline \multicolumn{6}{|c|}{ Ephyra diameter } \\
\hline Mean & 5.97 & 4.02 & 3.13 & 2.66 & 3.05 \\
\hline Range & $5-7.5$ & $3-5$ & $2-4$ & $1.5-3.1$ & $2-4.1$ \\
\hline $\mathrm{SD}^{\circ}$ & 0.459 & 0.597 & 0.399 & 0.431 & 0.459 \\
\hline \multicolumn{6}{|c|}{ Arms per ephyra } \\
\hline Mean & 15.7 & 8.1 & 7.9 & 8.2 & 8.05 \\
\hline Range & $14-18$ & $6-12$ & $6-10$ & $7-10$ & $7-10$ \\
\hline SD & 1.05 & 1.37 & 1.17 & 0.676 & 0.555 \\
\hline \multicolumn{6}{|c|}{ Ephyra color } \\
\hline & $\begin{array}{l}\text { orange } \\
\text { yellow }\end{array}$ & $\begin{array}{c}\text { blonde/ } \\
\text { reddish } \\
\text { brown }\end{array}$ & $\tan$ & $\begin{array}{l}\text { clear, with } \\
\text { maroon } \\
\text { central ring }\end{array}$ & red \\
\hline
\end{tabular}

Note: Measurements are in millimeters. Data from cultures maintained by C.L.W. at the Monterey Bay Aquarium, Monterey, California, at $14^{\circ} \mathrm{C}, n=100$ for each species listed. One-way ANOVA tests were conducted to assess whether size of morphological features for each species were significant when compared with one another; for ephyrae diameter $F=784.825, \mathrm{df}=4, P<.001$; for arms per ephyrae $F=247.548, \mathrm{df}=4, P<.001$. 


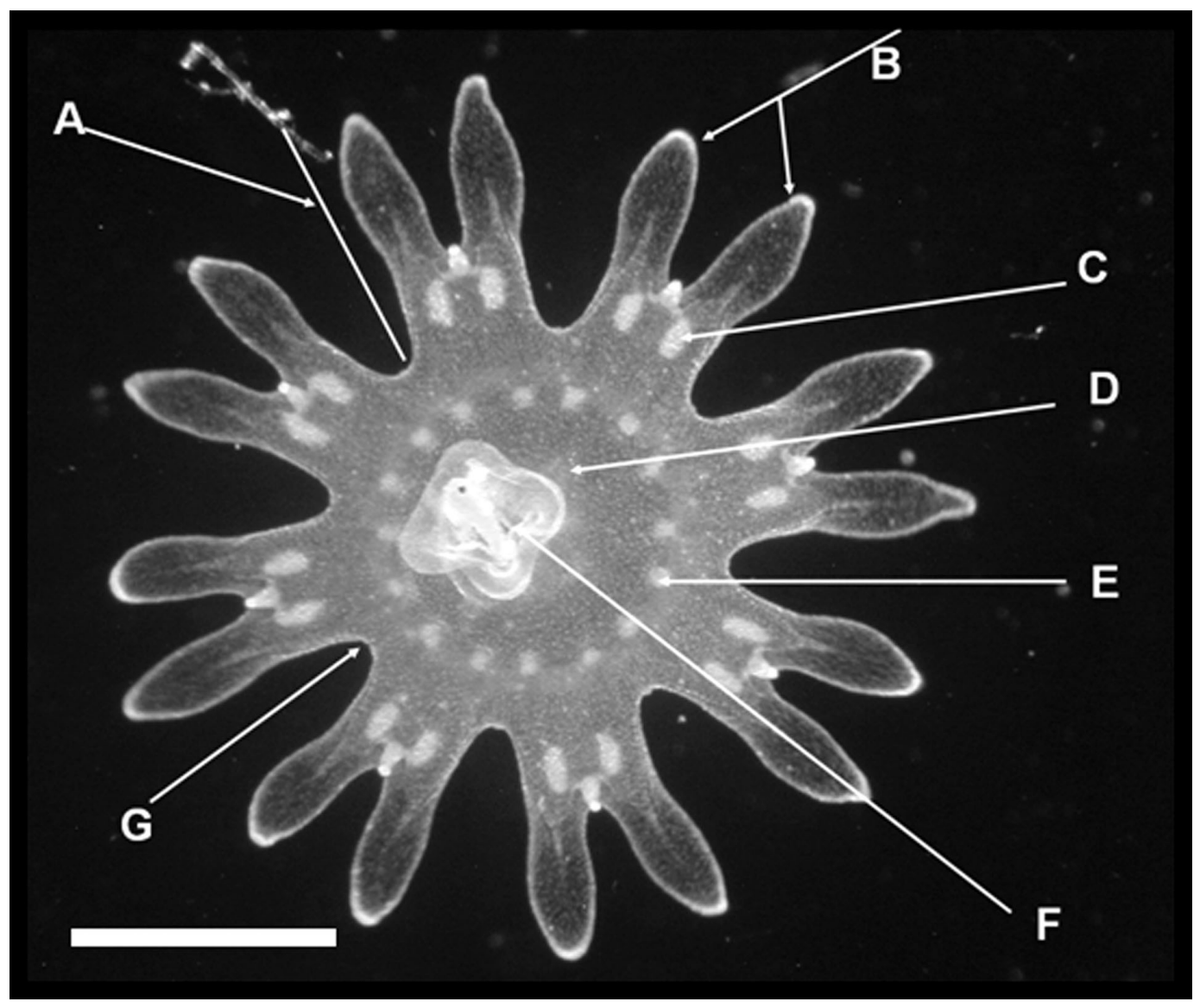

Figure 6. An ephyra for orientation. $A$, Rhopaliar arm. $B$, Lappets (note that there are two per arm). $C$, Elongated nematocyst battery. $D$, Gastric cirrus. $E$, Rounded nematocyst battery. $F$, Mouth. $G$, Cleft between rhopaliar arms. Scale bar $=1 \mathrm{~mm}$.

rather than uncommon individuals with fewer or more than four gut pouches. See Figure 6 for an orientation to general ephyra morphology.

\section{KEY TO NORTHEAST PACIFIC EPHYRAE}

1a. With 15-18 marginal arms, most commonly with 16 marginal arms, and nematocyst batteries scattered evenly over exumbrellar surface, with an additional smaller, single nematocyst battery present at subumbrellar base of each marginal arm and pointed lappets. Ephyra yellow to pale orange .......... Phacellophora camtschatica (Figure 7A)

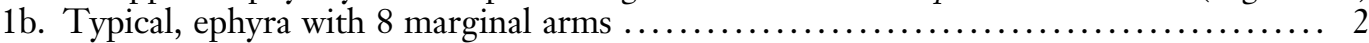

2a. With 8 arms and without distinct elongate paired nematocyst batteries on each rhopa-

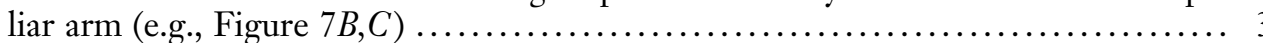

2b. With 8 arms and with distinct elongate paired nematocyst batteries on each rhopaliar arm (Figure 8) 


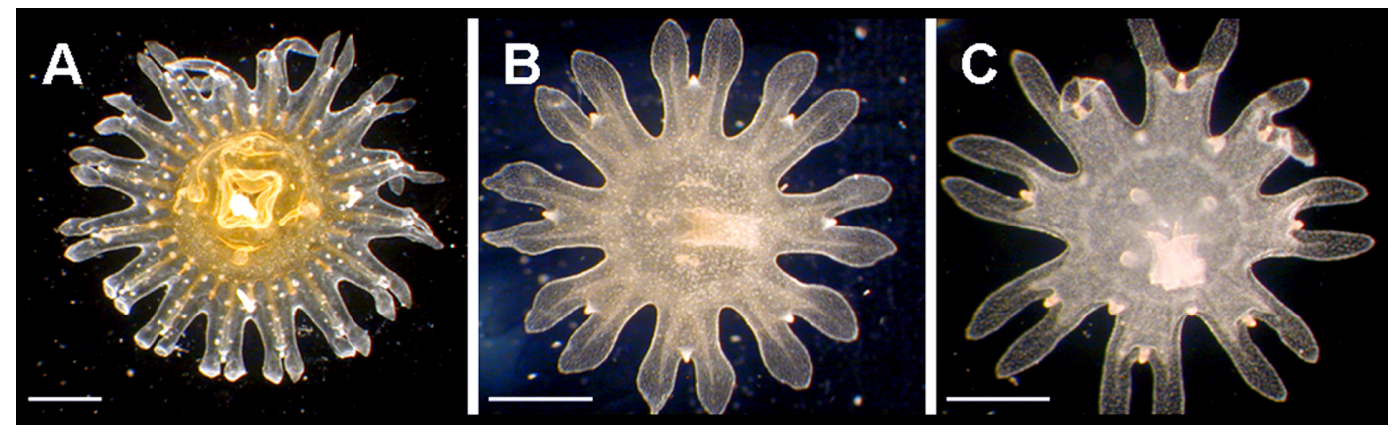

Figure 7. Ephyrae belonging to the families Ulmaridae and Cyaneidae. A, Phacellophora camtschatica. B, Aurelia labiata. C, Cyanea sp. Scale bars $=1 \mathrm{~mm}$.

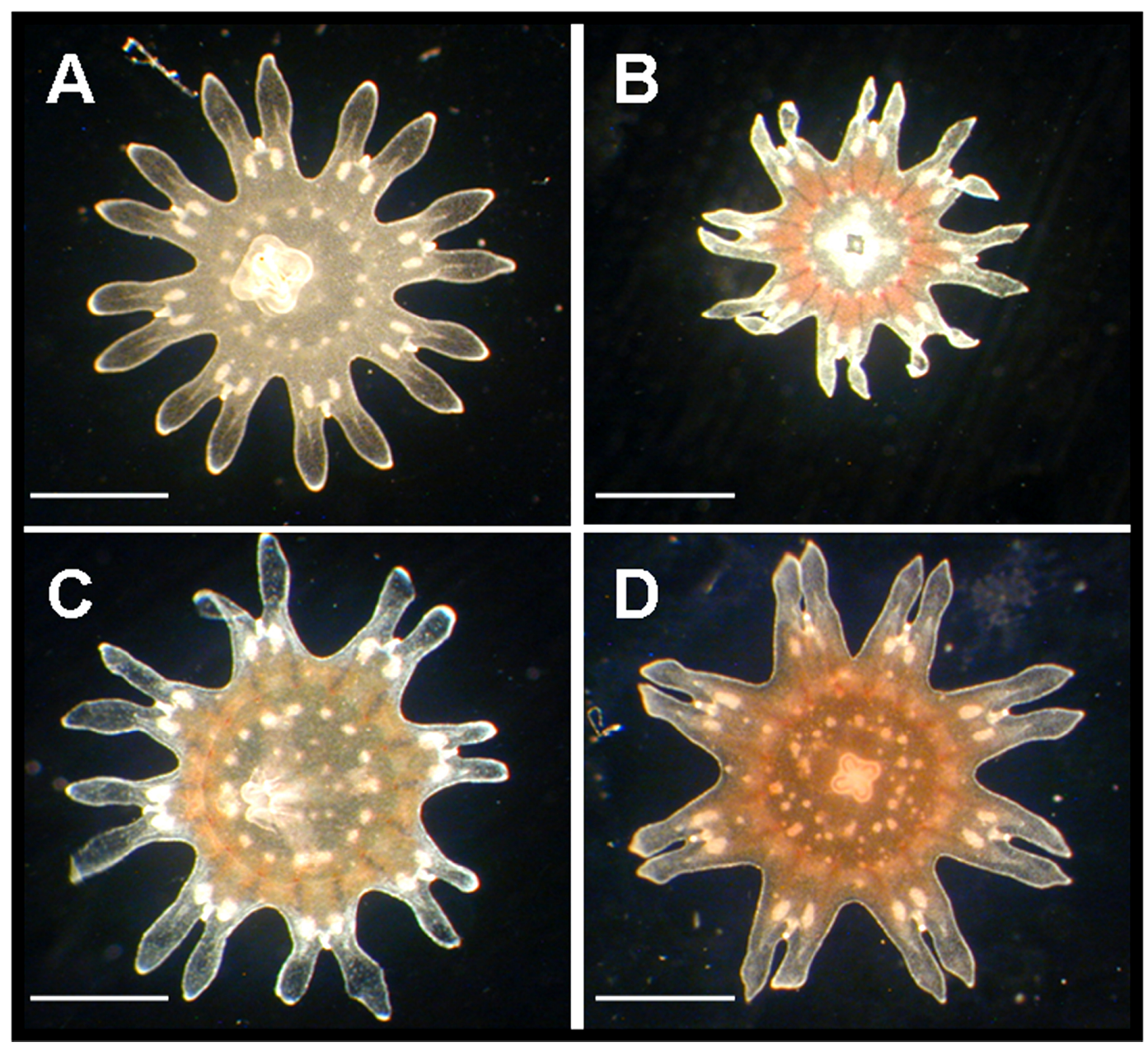

Figure 8. Ephyrae belonging to the family Pelagiidae. A, Chrysaora fuscescens. B, C. achlyos. C, C. colorata. D, C. melanaster. Scale bars $=1 \mathrm{~mm}$. 
3a. With 8 short and wide lappets (lappet as long as arm base is tall), with 2-3 gastric filaments per quadrant, pale orange to buff with bluntly rounded lappet

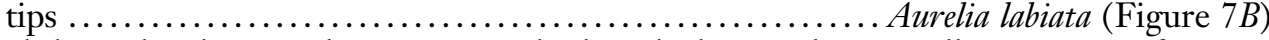

3b. With long thin lappets (lappets twice the length the arm base is tall), presence of one marginal tentacle rudimentary bud and possibly with one other on opposite side of ephyra bell, with only one gastric filament per quadrant, ephyrae pale pink to

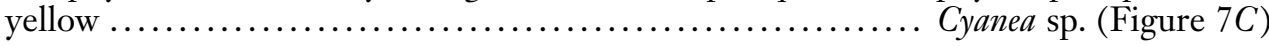

4a. With tan lappet tips, ephyrae pale buff or light tan and without any reddish coloration, with pairs of rounded nematocyst batteries at base of each rhopaliar arm forming a

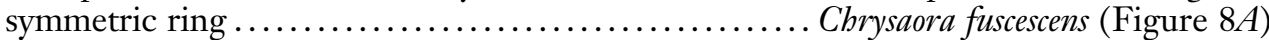

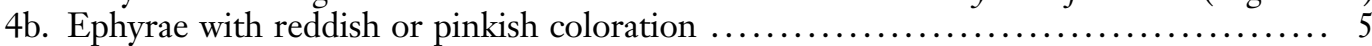

5a. With elongated nematocyst batteries near midpoint of rhopaliar arms, with pairs of rounded nematocyst batteries at base of each rhopaliar arm forming a symmetric ring, white lappet tips. Ephyrae with a reddish or maroon ring around perimeter of bell and without coloration in center of bell........... Chysaora achlyos (Figure 8B)

5b. With oval nematocyst batteries near midpoint of rhopaliar arms, with pairs of rounded nematocyst batteries at base of each rhopaliar arm forming a symmetric ring, with translucent white lappet tips. Ephyrae reddish throughout entire

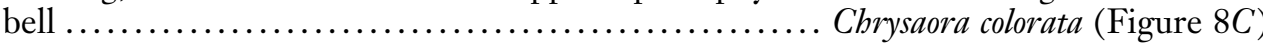

5c. With elongated nematocyst batteries near midpoint of rhopaliar arms, pink lappet tips, with unevenly scattered rounded nematocyst batteries over entire bell. Ephyrae pinkish or reddish over entire bell ............... Chrysaora melanaster (Figure 8D)

\section{ACKNOWLEDGMENTS}

I thank all of the reviewers at Monterey Bay Aquarium and Monterey Bay Aquarium Research Institute, and also A. Morandini and an anonymous one for their extremely valuable comments that helped to improve the overall quality of the manuscript. I also thank George Z. Peterson, diving safety officer at Monterey Bay Aquarium, for helping with medusa collections. Thank you also to Carol L. Widmer, H. Rollins, G. Simmons, and Ray at the Portola for all their support and guidance. I also thank Humboldt State University, the men of $D$ Company 2/34th Armor, and the U.S. Army College Fund for the education. And thanks to the Monterey Bay Aquarium for the opportunity.

\section{Literature Cited}

Arai, M. N. 1997. A functional anatomy of the scyphozoa. Chapman and Hall, London.

- 2005. Predation on pelagic coelenterates: A review. J. Mar. Biol. Assoc. U. K. 85:523-536.

Brewer, R. H., and J. S. Feingold. 1991. The effect of temperature on the benthic stages of Cyanea (Cnidaria: Scyphozoa), and their seasonal distribution in the Niantic River estuary, Connecticut. J. Exp. Mar. Biol. Ecol. 152:49-60.

Chen, J., and G. Ding. 1983. Effect of temperature on the strobilation of jellyfish (Rhopilema esculenta KishinouyeScyphozoa, Rhizostomeae). Zool. Sin. 29:195-206.

Chen, J., G. Ding, and C. Liu. 1984. Effect of light on the strobilation of edible medusa, Rhopilema esculenta Kishinouye (Cnidaria, Scyphozoa). Oceanol. Limnol. Sin. 15: 310-316.

- 1985. Effect of nutritional conditions on the strobilation of edible medusa, $R b_{0}-$ pilema esculenta Kishinouye. J. Fish. China 9:321-329.

Condon, R. H., M. B. Decker, and J. E. Purcell. 2001. Effects of low dissolved oxygen on survival and asexual reproduction of scyphozoan polyps (Chrysaora quinquecirrba). Hydrobiologia 451:89-95.

Gershwin, L. 2001. Systematics and biogeography of the jellyfish Aurelia labiata 
(Cnidaria: Scyphozoa). Biol. Bull. (Woods Hole) 201:104-119.

Gershwin, L., and A. G. Collins. 2002. A preliminary phylogeny of Pelagiidae (Cnidaria, Scyphozoa), with new observations of Chrysaora colorata comb. nov. J. Nat. Hist. 36:127-148.

Kramp, P. L. 1961. Synopsis of the medusae of the world. J. Mar. Biol. Assoc. U. K. 40:1-469.

Larson, R. J. 1990. Scyphomedusae and Cubomedusae from the eastern Pacific. Bull. Mar. Sci. 47:546-556.

Loeb, M. J. 1972. Strobilation in the Chesapeake Bay sea nettle Chrysaora quinquecirrba. I. The effects of environmental temperature changes on strobilation and growth. J. Exp. Zool. 180:279-292.

. 1973. The effect of light on strobilation in the Chesapeake Bay sea nettle Chrysaora quinquecirrha. Mar. Biol. (Berl.) $20: 144-147$.

Morandini, A. C., F. L. da Silveira, and G. Jarms. 2004. The life cycle of Chrysaora lactea Eschscholtz, 1829 (Cnidaria, Scyphozoa) with notes on the scyphistoma stage of three other species. Hydrobiologia 530/531:347-354.

Purcell, J. E., J. R. White, D. A. Nemazie, and D. A. Wright. 1999. Temperature, salinity and food effects on asexual reproduction and abundance of the scyphozoan
Chrysaora quinquecirrha. Mar. Ecol. Prog. Ser. 180:187-196.

Raskoff, K. A., F. A. Sommer, W. M. Hamner, and K. M. Cross. 2003. Collection and culture techniques for gelatinous zooplankton. Biol. Bull. (Woods Hole) 204:68-80.

Russell, F. S. 1970. The medusae of the British Isles. II. Pelagic Scyphozoa with a supplement to the first volume on hydromedusae. Cambridge University Press, Cambridge, U. K.

Schaadt, M., L. Yasukochi, L. Gershwin, and D. Wrobel. 2001. Husbandry of the black jelly (Chrysaora achlyos), a newly discovered scyphozoan in the eastern North Pacific Ocean. Bull. Inst. Oceanogr. (Monaco), spec. num. 20 (1): 289-296.

Shenker, J. M. 1984. Scyphomedusae in the surface waters of the Oregon coast, MayAugust, 1981. Estuarine Coastal Shelf Sci. 19:619-632.

- 1985. Carbon content of the neritic scyphomedusa C. fuscescens. J. Plankton Res. 7 (2): 169-173.

Widmer, C. L. 2006. The life cycle of Phacellophora camtschatica (Cnidaria: Scyphozoa). Invertebr. Biol. 125 (2): 83-90.

Wrobel, D., and C. E. Mills. 1998. Pacific coast invertebrates: A guide to the common gelatinous animals. Sea Challengers and Monterey Bay Aquarium, Monterey. 